J. Kundrák, A. Nagy, Miskolc, Hungary, A.P. Markopoulos, N.E. Karkalos, D. Skondras-Giousios, Athens, Greece

\title{
EXPERIMENTAL STUDY ON SURFACE ROUGHNESS OF FACE MILLED PARTS WITH ROUND INSERT AT VARIOUS FEED RATES
}

\begin{abstract}
In the present paper, the variation of surface roughness of machined parts during symmetrical face milling is investigated. During this experimental work, the effect of using a milling insert with a round geometry under various feed rate values on the topography of milled parts is examined. For that purpose, both $2 D$ and $3 D$ surface roughness measurements were performed in three planes parallel to the feed direction, with one of the planes being on the symmetrical plane and the other two being at the same distance from it but in opposite sides. The analysis of the experimental results indicated that although surface roughness increases gradually with increase of feed rate, a considerable increase of surface roughness occurs for feed rate values over $0.4 \mathrm{~mm} /$ tooth. Moreover, the overall higher surface roughness values were found to be on the symmetrical plane, which was also more affected by the increase of feed rate than the other two planes.
\end{abstract}

Keywords: surface roughness; symmetrical face milling; round insert; feed rate.

\section{INTRODUCTION}

Surface quality of mechanical components is considered very crucial, as it is one of the main indicators of surface integrity and it was shown to affect produced parts' life directly [1]. High surface quality at the last stages of the production can usually be obtained by abrasive processes suitable for finishing, like grinding or polishing, but it is also required to achieve sufficient surface quality from the early stages of manufacturing when turning or milling processes are carried out. In specific, face milling, which is widely used in the industrial environment, is used to create flat surfaces with high dimensional accuracy, appropriate flatness and high surface quality.

Surface roughness is one of the most important aspects of surface quality. For that reason, many scientific works regarding surface roughness during face milling have already been reported in the relevant literature. In the existing experimental studies, it was shown that surface roughness decreases at high cutting speed values [2-4], possibly due to more stable conditions. Moreover, improved machining performance was observed at intermediate and high speeds $[3,4]$; on the contrary, lower values of cutting speed were related to built-up edge creation and chip fracture, leading to deterioration of surface quality [2,3]. The increase of feed rate, axial and radial depth of cut also lead to surface quality

(C) J. Kundrák, A. Nagy, A.P. Markopoulos, N.E. Karkalos, D. Skondras-Giousios, 2020 
deterioration [2-4] and particularly, the feed rate is considered as the parameter that mostly affects surface roughness [5,6].

Various researchers have used different approaches for predicting surface roughness. Torra et al. [7] developed a surface morphology prediction model for high feed milling able to consider different geometries, tool configurations and real cutting vibrations with negligible errors. Arizmendi and Jimenez [8] proposed a methodology for predicting the 3D topography based on the kinematics of the face milling process, which can be applied to various insert geometries. By using a regularly spaced grid of points along the feed and pick feed direction they were able to sufficiently predict the surface roughness, including runout effects, as a good agreement was found with experimental face milling tests. Felhö et al. [9] presented a detailed approach for the modeling of surface roughness during face milling with different cutting insert geometries, such as polygonal, round and triangular. The insert geometrical features were modeled, and the technological parameters of the process were taken into account, so that the calculation of the surface topography was possible based on the insert trajectory relative to the workpiece. With this model, sufficient accuracy of the prediction of $R_{a}$ and $R_{t}$ was achieved, compared to experimental results. Moreover, Jin et al. [10] presented a unified prediction model of 3D surface topography in face milling, considering multierror sources, with cutting wipers on the inserts. The model could generate point cloud to simulate the machined surface topography and was established by considering the insert geometry, machining process parameters and toolworkpiece dynamics, and integrating them with several error sources. Svalina et al. [11] employed an alternative approach by correlating 23 machined surface images with their actual roughness statistical measurements.

In addition to the above-mentioned works, few researchers have employed artificial intelligence methods for surface roughness prediction. Pimenov et al. [12] compared various methods such as random forest, multilayer perception, radial-basis functions and regression trees for the prediction of surface roughness by monitoring the tool wear. The analysis of the results showed that random forest and regression tree methods exhibited higher accuracy and could provide essential information about the relation of input and output variables, as well as their critical values. Abbas et al. [13] used ANN with the Edgeworth-Pareto method for a face milling operation in order to optimize the cutting conditions, e.g. cutting speed, depth of cut and feed per tooth for a desired value of $\mathrm{R}_{\mathrm{a}}$. Alharthi et al. [1] developed an ANN model and regression analysis model to predict surface roughness for different values of spindle speed, depth of cut and feed rate. After experimental validation tests, both models were able to predict $R_{a}$ with an accuracy of about 
95\% and 94\%, respectively. In addition, a higher surface roughness with increasing feed rate was reported.

Although most researchers investigate the effect of process parameters values on surface roughness, the effect of milling strategy, such as symmetric or asymmetric milling on the surface quality during face milling has rarely been investigated. Bağci and Aykut [14] compared symmetric and asymmetric face milling strategies, showing that during symmetric milling a lower value of roughness was obtained. Pimenov et al. [15] investigated the effect of the relative position of the milling cutter, which characterizes the face milling process kinematics and affects the contribution of up and down milling. It was found that this factor directly affected milling vibrations, cutting forces and surface roughness and the lowest values of vibrations and cutting forces were observed for the case of up-milling. Finally, they were able to optimize the relative position of the milling cutter for obtaining better machining conditions such as reducing the roughness parameter.

In the present work, an experimental study is conducted with a view to determine the effect of feed rate values on workpiece surface quality during face milling. Contrary to most of the works in the relevant literature, both 2D and 3D surface roughness parameters are determined not only in a single position or plane but in three different parallel planes on the feed direction in order to be able to determine the variation of surface roughness with the distance from the symmetric plane.

\section{EXPERIMENTAL CONDITIONS}

The experimental tests in the present paper were carried out regarding face milling of normalized C45, 1.0503 grade carbon steel workpieces, using a single cutting insert at various feed rate values. More specifically, milling experiments were performed in a Perfect Jet MCV-M8 CNC vertical machining center with a face milling head with only one round coated carbide insert of RCKT1204M0-PM type mounted on it. The cutting length was $50 \mathrm{~mm}$ and the width of cut $58 \mathrm{~mm}$ on the milled surfaces of the samples. During the experimental procedure the feed per tooth $\mathrm{f}_{\mathrm{z}}$ values ranged from 0.1 to 0.8 $\mathrm{mm} /$ tooth and the other process parameters such as the cutting speed $\mathrm{v}_{\mathrm{c}}$ and depth of cut $\mathrm{a}_{\mathrm{p}}$ were held constant at $200 \mathrm{~m} / \mathrm{min}$ and $0.8 \mathrm{~mm}$, respectively. The process parameters' values for the face milling experiments are also presented in Table 1.

The face milling head had a nominal diameter $\left(D_{t}\right)$ of $68 \mathrm{~mm}$ and the rake $\left(\gamma_{0}\right)$ and relief angle $\left(\alpha_{0}\right)$ of the insert were $0^{\circ}$ and $7^{\circ}$, respectively. The hardness of the workpiece material was HB207 and the tensile strength $\mathrm{R}_{\mathrm{m}}$ was $580 \mathrm{MPa}$ [16]. The surfaces were produced with symmetrical setting of face milling under dry machining conditions. 
Table 1 - Process parameters' values for the face milling experiments

\begin{tabular}{|c|c|c|c|c|}
\hline No. & $\mathbf{a}_{\mathbf{e}}[\mathrm{mm}]$ & $\mathbf{a}_{\mathbf{p}}[\mathrm{mm}]$ & $\mathbf{v}_{\mathbf{c}}[\mathrm{m} / \mathrm{min}]$ & $\mathbf{f}_{\mathbf{z}}[\mathrm{mm} /$ tooth $]$ \\
\hline 1 & \multirow{5}{*}{58} & \multirow{5}{*}{0.8} & \multirow{5}{*}{200} & 0.1 \\
\hline 2 & & & & 0.2 \\
\hline 3 & & & & 0.3 \\
\hline 4 & & & & 0.4 \\
\hline 5 & & & & 0.8 \\
\hline
\end{tabular}

The 2D and 3D roughness measurements were carried out on an AltiSurf 520 threedimensional surface roughness measuring device and a confocal chromatic sensor was employed to perform the measurements. The evaluation of the results, as well as the calculation of $2 \mathrm{D}$ and $3 \mathrm{D}$ roughness parameters after the measurements, was conducted using AltiMap Premium software. Roughness was measured in three planes parallel to the direction of feed with the one plane being the middle plane and the two planes being at equal distance $(20 \mathrm{~mm})$ from that and towards different sides. It is to be noted that the last two planes will be denoted afterwards as entry and exit side plane. The measurements were performed twice in each plane with a $20 \mathrm{~mm}$ separation between them, as presented in Figure 1. In accordance with ISO 4288:1998, the lengths of the $2 \mathrm{D}$ measurements were $4 \mathrm{~mm}$, whereas for the $3 \mathrm{D}$ evaluations, the surface roughness on areas of $2.5 \times 2.5$ was recorded. The aforementioned lengths and areas are illustrated with lines and squares, respectively, in Figure 1, in respect to the milling head rotation and the workpiece movement directions.



Figure 1 - Surface roughness measurements locations on the workpiece surface 


\section{RESULTS}

After the face milling experiments were carried out, surface roughness measurements were performed on the machined samples, each repeated three times and then the results were processed by the aforementioned software in order to determine the values of surface roughness parameters. In Tables 2 and 3 , as well as Figure 2, the average values of 2D and 3D roughness parameters, namely $\mathrm{Ra}, \mathrm{Rz}, \mathrm{Sa}$ and $\mathrm{Sz}$ for the three parallel planes and five different feed rate values are displayed.

In addition to the average values of $2 \mathrm{D}$ and $3 \mathrm{D}$ surface roughness parameters, the recorded 2D and 3D surface roughness profiles will be afterwards presented in Figures 3 and 4 for $\mathrm{fz}=0.1,0.3$ and $0.8 \mathrm{~mm} /$ tooth, in order to show more directly the effect of different feed rate values on the surface topography during face milling.

Table 2 - 2D surface roughness parameters' values in three parallel planes

\begin{tabular}{|c|c|c|c|c|c|c|}
\hline \multirow{2}{*}{$\begin{array}{c}\mathbf{f}_{\mathbf{z}} \\
{[\mathrm{mm} / \text { tooth }]}\end{array}$} & \multicolumn{3}{|c|}{ Ra $[\mu \mathrm{m}]$} & \multicolumn{3}{c|}{ Rz $[\mu \mathrm{m}]$} \\
\cline { 2 - 7 } & Entry & Symm. & Exit & Entry & Symm. & Exit \\
\hline 0.1 & 0.605 & 0.747 & 0.683 & 3.909 & 4.012 & 3.984 \\
\hline 0.2 & 0.975 & 0.868 & 1.393 & 6.272 & 4.923 & 7.581 \\
\hline 0.3 & 0.933 & 0.927 & 0.922 & 6.272 & 4.652 & 5.381 \\
\hline 0.4 & 0.807 & 0.949 & 0.750 & 4.626 & 4.731 & 4.467 \\
\hline 0.8 & 1.704 & 2.971 & 1.703 & 9.822 & 15.375 & 9.902 \\
\hline
\end{tabular}

Table 3-3D surface roughness parameters' values in three parallel planes

\begin{tabular}{|c|c|c|c|c|c|c|}
\hline $\begin{array}{c}\mathbf{f}_{\mathbf{z}} \\
{[\mathrm{mm} / \text { tooth }]}\end{array}$ & \multicolumn{3}{|c|}{ Sa $[\mu \mathrm{m}]$} & \multicolumn{3}{c|}{ Sz $[\mu \mathrm{m}]$} \\
\cline { 2 - 7 } & Entry & Symm. & Exit & Entry & Symm. & Exit \\
\hline 0.1 & 0.635 & 0.964 & 1.461 & 3.012 & 5.091 & 7.462 \\
\hline 0.2 & 1.021 & 0.908 & 1.815 & 5.338 & 4.440 & 7.782 \\
\hline 0.3 & 0.952 & 0.988 & 0.874 & 4.148 & 4.486 & 4.038 \\
\hline 0.4 & 0.885 & 0.999 & 0.828 & 4.523 & 4.907 & 4.431 \\
\hline 0.8 & 1.911 & 2.723 & 1.746 & 8.716 & 12.442 & 7.956 \\
\hline
\end{tabular}

\section{DISCUSSION}

The topography of the machined surfaces during face milling is considerably affected by the kinematics of this process. More specifically, during face milling, a rotating milling head is used, on which the cutting insert is mounted, and the workpiece moves with a fixed velocity relative to the cutting tool. Furthermore, during symmetrical face milling, where the 
axis of the cutting tool is moving along the symmetrical plane of the machined part, the action of the cutting insert in the first half of the chip removal process corresponds to the up-milling process, whereas in the second half the chip removal process corresponds to a down-milling process. For that reason, after the face milling experiments, it is important to conduct surface roughness measurements not only on the symmetrical or middle plane, but also in parallel planes on two opposite sides. Based on the experimental results, presented in Tables 2 and 3 and depicted in Figure 2, it can be observed that surface roughness values, especially $\mathrm{Ra}$ and $\mathrm{Sa}$ generally increase with an increase of feed rate, as it was anticipated. Regarding $\mathrm{Ra}$, this increase is gradual up to $0.4 \mathrm{~mm} /$ tooth and then $\mathrm{Ra}$ is increased considerably for $\mathrm{f}_{\mathrm{z}}=0.8 \mathrm{~mm} /$ tooth. Sa values remain practically unchanged up to $0.4 \mathrm{~mm} /$ tooth and then increase sharply, and the same trend is observed for $\mathrm{Rz}$ and $\mathrm{Sz}$ as well. The increasing trend of surface roughness with higher feed rate values and the sharp rise of its values at $f_{z}=0.8$ $\mathrm{mm} /$ tooth can be also seen in the 2D surface roughness profile, depicted in Figure 3. From Figure 3, it becomes evident that the height of the profiles becomes much larger at the highest feed rate value.

When the surface roughness values in the case with the lowest and highest feed rate values were compared on the symmetrical plane, it was found that $\mathrm{Ra}$ increased by 3.98 times, $\mathrm{Rz}$ by 3.83 times, Sa by 2.82 times and $\mathrm{Sz}$ by 2.44 times. On the entry side, Ra increased by 2.82 times, Rz by 2.51 times, Sa by 3.01 times and $\mathrm{Sz}$ by 2.89 times. Moreover, on the exit side, $\mathrm{Ra}$ increased by 2.49 times, Rz by 2.49 times, Sa by 1.19 times and $\mathrm{Sz}$ by 1.07 times. From these findings, it can be observed that the effect of increasing feed rate values was more important on the symmetrical plane than the other two planes, on which the increase of roughness values regarding $\mathrm{Ra}$ and $\mathrm{Rz}$ was almost similar and lower than that on the symmetrical plane. When the surface roughness values between different planes are compared, it can be clearly seen that the highest overall values, for the highest feed rate value are recorded on the symmetrical plane. However, in the other cases the surface roughness is not always higher on the symmetrical plane and the highest values can be observed on the entry or exit side as well. Regarding the difference between $\mathrm{Ra}$ and $\mathrm{Sa}$ values between the symmetrical plane and other two planes, it becomes smaller for $f_{z}=0.3$ $\mathrm{mm} /$ tooth, implying that the roughness profile becomes more homogenous in this case, as average roughness values are almost similar in all planes. 


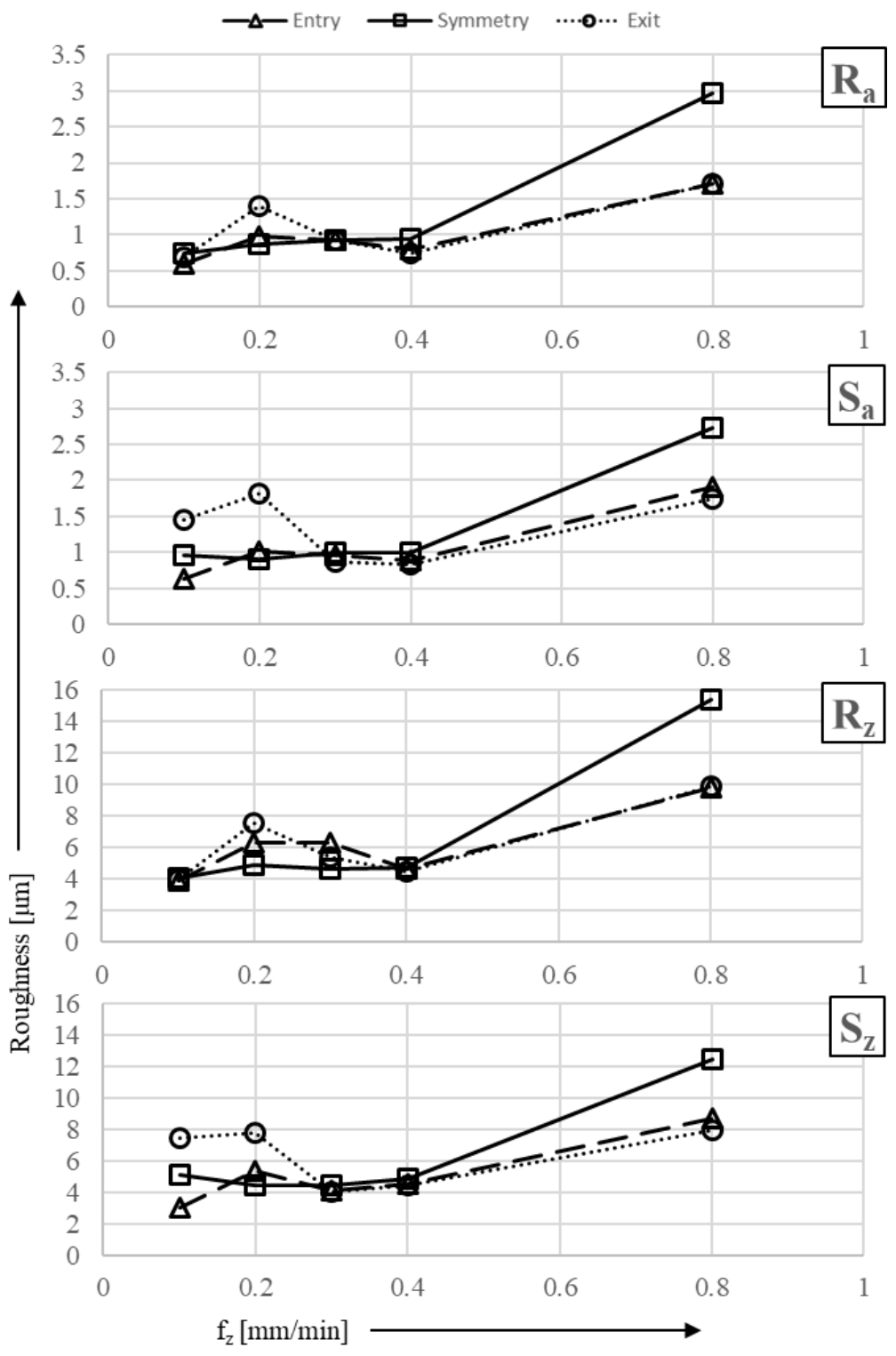

Figure 2-2D and 3D surface roughness parameters' values at the three parallel planes for various feed rate values 


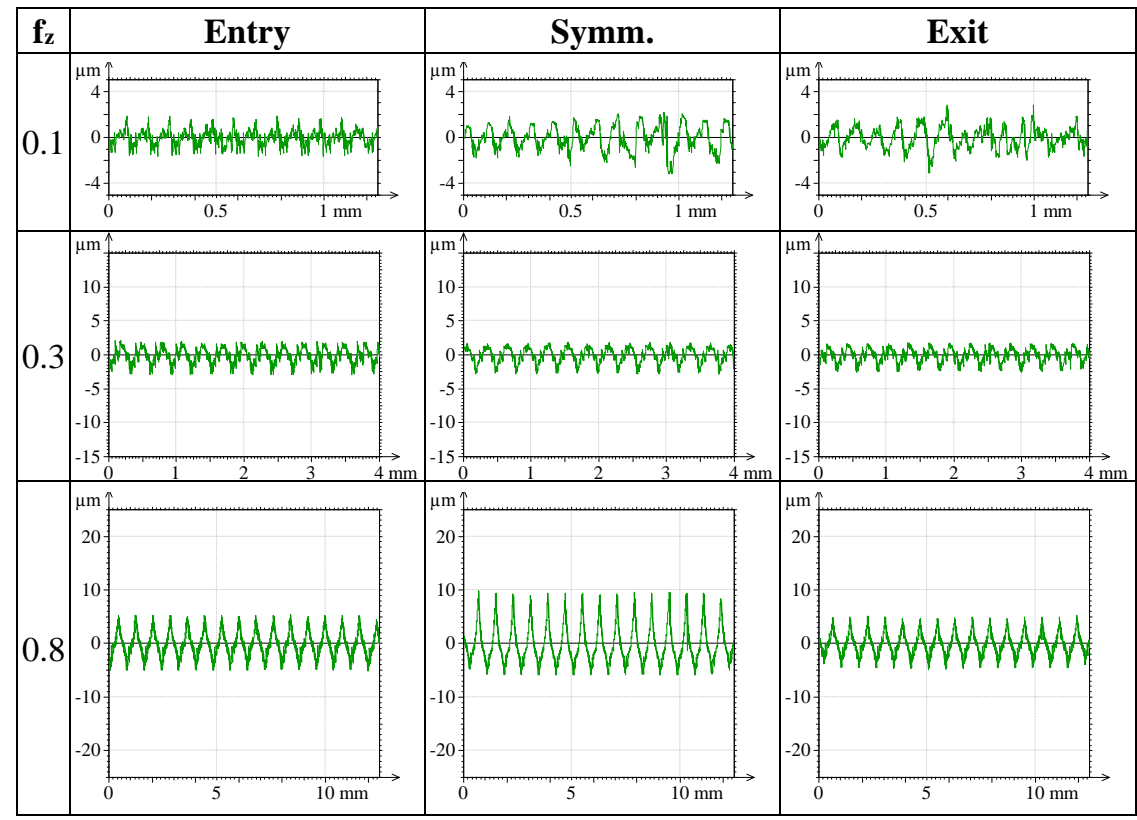

Figure $3-2 \mathrm{D}$ roughness profiles of the milled surfaces at different feed rates at three parallel planes

The variations in surface topography of the milled workpieces under different feed rates can be also seen in the 3D surface roughness graphs of Figure 4. At first, it can be understood that the shape of the grooves is indicative of the location of each measurement, as arc shaped grooves occur in the entry and exit side, whereas on the symmetrical plane almost straight grooves are formed. However, differences regarding the grooves dimensions are more important for surface quality. The difference between the profiles are not only in the height of the profile, which is much bigger in the case with $\mathrm{f}_{\mathrm{z}}=$ $0.8 \mathrm{~mm} /$ tooth, but also in the spacing between the micro-grooves formed on the surfaces. As it was aforementioned, the kinematics of the face milling process directly affect the shape of the profile, with a higher feed rate leading to larger spacing between adjacent grooves and also higher height of the profile. In the case with the lowest feed rate, the 3D profile seems less smooth, as irregularities of the surface are comparable to the dimensions of the grooves, whereas for higher feed rates, as the grooves become deeper and spacing between them is increased, these irregularities become less significant. However, the adverse result of surface quality deterioration at the 
highest feed rate value becomes obvious by comparing the $3 \mathrm{D}$ profiles at every parallel plane.

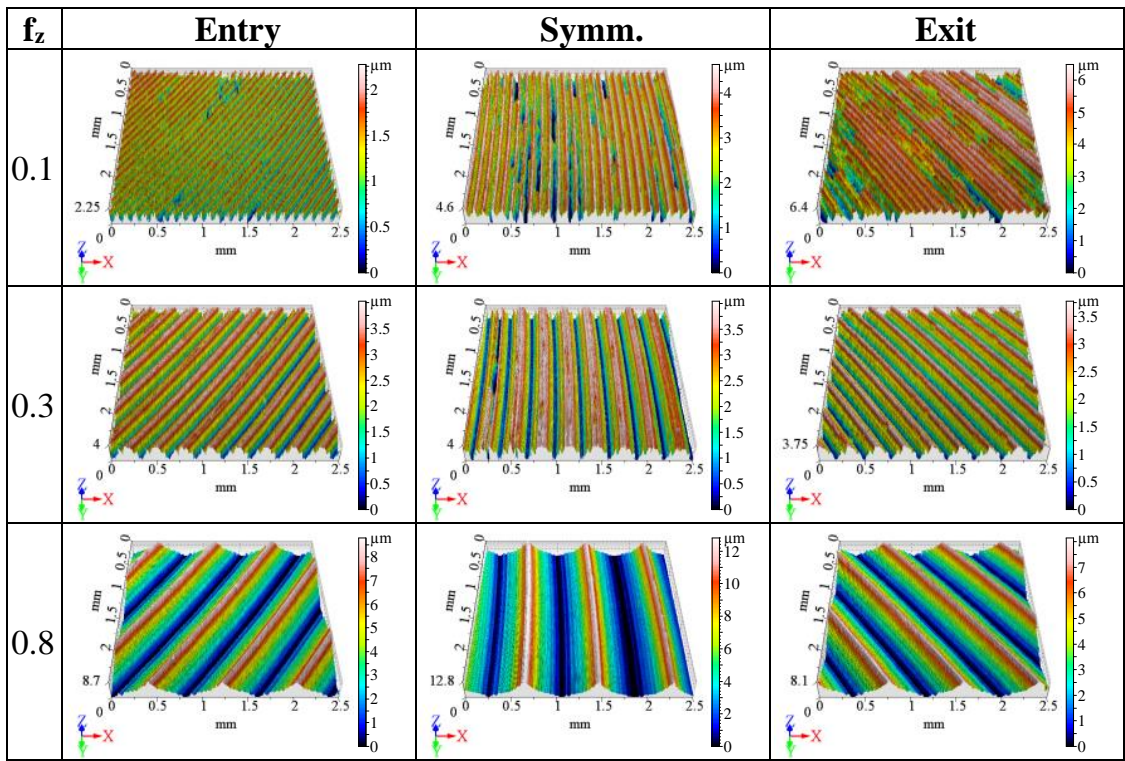

Figure $4-3 D$ roughness profiles of the milled surfaces at different feed rates at three parallel planes

\section{CONCLUSIONS}

In the present work, symmetrical face milling experiments on steel workpieces at different feed rate values were carried out with the use of a single round insert, with a view to determine the effect of feed rate on surface topography of the milled parts. The surface quality was examined in every case in three planes parallel to the feed direction and both 2D and 3D surface roughness parameters were determined. From the analysis of the experimental results, various important conclusions were drawn.

The values of all surface roughness parameters showed a variation with feed rate, with a considerable rise for feed values over $0.4 \mathrm{~mm} /$ tooth, whereas the variation was minimal for lower values of feed. From these findings, it became clear that feed value should be selected lower than $0.4 \mathrm{~mm} /$ tooth in order to achieve an acceptable surface quality, with Ra lower than $1 \mu \mathrm{m}$. The highest increase of roughness values was observed on the symmetrical plane, 
as well as the largest overall values of every surface roughness parameter. Finally, it was found that the minimum difference of $\mathrm{Ra}$ and $\mathrm{Sa}$ values between the symmetrical and the other two planes was achieved for $f_{z}=0.3 \mathrm{~mm} /$ tooth.

\section{ACKNOWLEDGMENTS}

The authors greatly appreciate the support of the National Research, Development and Innovation Office - NKFIH (No. of Agreement: K 116876).

The described study was carried out as part of the EFOP-3.6.1-16-00011 "Younger and Renewing University - Innovative Knowledge City institutional development of the University of Miskolc aiming at intelligent specialization" project implemented in the framework of the program Szechenyi 2020.

Both grants are gratefully acknowledged.

References: 1. Alharthi, N.H., Bingol, S., Abbas, A.T., Ragab, A.E., El-Danaf, E.A., Alharbi, H.F.: Optimizing cutting conditions and prediction of surface roughness in face milling of AZ61 using regression analysis and artificial neural network, Advances in Materials Science and Engineering, 7560468. (2017) 2. Subramanian, A.V.M., Nachimuthu, M.D.G, Cinnasamy, V.: Assessment of cutting force and surface roughness in $\mathrm{LM} 6 / \mathrm{SiCp}$ using response surface methodology, Journal of Applied Research and Technology 15, pp. 283-296. (2017) 3. Pathak, B.N., Sahoo, K.L., Mishra, M.: Effect of Machining Parameters on Cutting forces and surface roughness in Al-(1-2) Fe-1V-1Si Alloys, Materials and Manufacturing Processes 28(4), pp. 463-469. (2013) 4. Hernandez-Gonzalez, L.W., Perez-Rodriguez, R., Quesada-Estrada, A.M., Dumitrescu, L.: Effects of cutting parameters on surface roughness and hardness in milling of AISI 304 steel, Dyna 85(205), pp. 57-63. (2018) 5. Selaimia, A.A., Yallese,M.A., Bensouilah, H., Meddour, I., Khattabi, R., Mabrouki,T.: Modeling and optimization in dry face milling of X2CrNi18-9 austenitic stainless steel using RMS and desirability approach, Measurement 107, pp. 53-67. (2017) 6. Hoang, T.D., Nguyen, N.T., Tran, D.Q., Nguyen, V.T.: Cutting forces and surface roughness in face milling of SKD61 hard steel, Journal of Mechanical Engineering 65(6), pp. 375385. (2019) 7. Torta, M., Albertelli, P., Monno, M.: Surface morphology prediction model for milling operations, The International Journal of Manufacturing Technology 106(7-8), pp.31893201. (2020) 8. Arizmendi, M., Jiménez, A.: Modelling and analysis of surface topography generated in face milling operations, International Journal of Mechanical Sciences 163, pp. 105061. (2019) 9. Felhö, C., Karpuschewski, B., Kundrák, J.: Surface roughness modeling in face milling, Procedia CIRP 31, pp. 136-141. (2015) 10. Jin, S., Liu, S., Zhang, X., Chen, K.: A unified prediction model of $3 \mathrm{D}$ surface topography in face milling considering multi-error sources, The International Journal of Advanced Manufacturing Technology 102 (1-4), pp. 705-717. (2019). 11. Svalina, I., Havrlišan, S., Šimunović, K., Šarić, T.: Investigation of Correlation between Image Features of Machined Surface and Surface Roughness, Tehnički vjesnik, 27(1), pp. 27-36. (2020) 12. Pimenov, D.Yu.,Bustillo, A., Mikolajczyk, T.: Artificial intelligence for automatic prediction of required surface roughness by monitoring wear on face mill teeth, Journal of Intelligent Manufacturing 29(5), pp. 1045-1061. (2018) 13. Abbas, A.T., Pimenov, D.Y., Erdakov, I.N., Mikolajczyk, T., Soliman, M.S., El Rayes, M.M.: Optimization of cutting conditions using artificial neural networks and the Edgeworth-Pareto mehod for CNC face-milling operations on highstrength grade-H steel, The International Journal of Advanced Manufacturing Technology 105(5), pp. 2151-2165. (2019) 14. Bağci, E., Aykut, Ş.: Influence of symmetric and asymmetric machining strategies on surface roughness in face milling process of cobalt-based superalloy, Journal of the 
Balkan Tribological Association 19(1), pp. 23-26. (2013) 15. Pimenov, D.Y., Hassui, A., Wojciechowski, S., Mia, M., Magri, A., Suyama, D.L., Bustillo, A., Krolczyk, G., Gupta, M.K.: Effect of the relative position of the face milling tool towards the workpiece on machined surface roughness and milling dynamics, Applied Sciences 9(5), pp. 842. (2019) 16. European Steel and Alloy Grades, C45, https://tinyurl.hu/GtDr/.

Янош Кундрак, Антал Надь, Мішкольц, Угорщина, Ангелос П. Маркопулос, Ніколаос Е. Каркалос, Дімітрос Скондрас-Гіусіос, Афіни, Греція

\title{
ЕКСПЕРИМЕНТАЛЬНЕ ДОСЛІДЖЕННЯ ШОРСТКОСТІ ОБРОБЛЕНОЇ ТОРЦЕВИМ ФРЕЗЕРУВАННЯМ ПОВЕРХНІ ФРЕЗОЮ 3 КРУГЛИМИ ВСТАВКАМИ ПРИ РІЗНИХ ШВИДКОСТЯХ ПОДАЧІ
}

\begin{abstract}
Анотація. $\quad$ У даній роботі досліджується зміни параметрів шорсткості поверхні оброблюваних деталей при симетричному ториевому фрезеруванні. $B$ ході иієї експериментальної роботи досліджується вплив використання фрезерної пластини 3 круглою геометрією при різних значеннях швидкості подачі на топографію фрезерованих деталей. Для иієї мети були виконані як двомірні, так $і$ тривимірні вимірювання шорсткості поверхні в трьох площинах, паралельних напрямку подачі, причому одна з площин перебувала на симетричній площині, а дві інші перебували на тій же відстані від неї, але в протилежних сторонах. Експериментальні випробування в цій статті були проведені відносно ториевого фрезерування заготовок з нормалізованої вуглецевої сталі марки C45, 3 використанням однієї ріжучої пластини при різних значеннях швидкості подачі. $2 D$ i $3 D$ вимірювання шорсткості були виконані на тривимірному пристрої вимірювання шорсткості поверхні AltiSurf 520, $i$ для виконання вимірювань використовувався конфокальний хроматичний датчик. Відмінності в топографії поверхні фрезерованих заготовок при різних швидкостях подачі полягають в тому, що форма канавок вказує на місие розташування кожного вимірювання, так як канавки у формі дуги зустрічаються на стороні входу $i$ виходу, тоді як на симетричній площині утворюються майже прямі канавки. Однак відмінності в розмірах канавок важливіші для якості поверхні. Різниия між профілями полягає не тільки в висоті профілю, яка значно більше в разі $f_{z}=0,8$ мм / зуб, але також в відстані між мікроканавками, сформованими на поверхнях. Кінематика процесу ториевого фрезерування безпосередньо впливає на форму профілю, причому більш висока швидкість подачі призводить до більшої відстані між сусідніми канавками, а також до більшої висоти профілю. У випадку з найнижчою швидкістю подачі тривимірний профіль виглядає менш гладким, оскільки нерівності поверхні можна порівняти з розмірами канавок, тоді як для більш високих швидкостей подачі, коли канавки стають глибшими і відстань між ними збільшується, иі нерівності стати менш значущими.
\end{abstract}

Ключові слова: иорсткість поверхні; симетричне ториеве фрезерування; кругла вставка; швидкість подачі. 